\title{
Building Social Welfare Through Social Security Based on The Socio- Economic Justice During COVID-19 Pandemic Crisis
}

\author{
Muhammad Rafi'i' ${ }^{1}$, Zaid $^{2}$ \\ ${ }^{1,2}$ Master of Law, Universitas Muhammadiyah Yogyakarta, D.I. Yogyakarta. raficorby15@gmail.com
}

Received: 23/06/2021.

Reviewed: 22/08/2021.

Published: 31/12/2021.

Copyright $\odot 2021$ by the author (et al) and Jurnal Sosial Humaniora (JSH)

*This work is licensed under the Creative Commons Attribution International License (CC BY 4.0). http://creativecommons.org/licenses/by/4.0/

\begin{abstract}
Subject Area: Law \& Socio-economics
Abstract

The purpose of this paper is to examine and analyze based on the principles of social and economic justice on how to grow prosperity during a recession in the midst of the COVID-19 pandemic as it is today through the strategy of providing social security to affected communities. By involving literature review or normative research methods along with a qualitative approach and legislation, this study found that the law on the security system stipulates that social security includes six forms of social security, including health security, work accident security, old-age security, pension security, death security, and job loss security. it's just that the problem is for those who do not pay dues or participate in the government's social security program. Their welfare must also be considered as mandated by the constitution of the 1945 Constitution. And in the principle of socio-economic justice, social security must be prioritized for the poor and underprivileged who are felt to be in more social need to achieve equity and social welfare.
\end{abstract}

Keywords: social welfare; social security; socio-economic justice; COVID19 pandemic

\section{Introduction/Background}

The COVID-19 pandemic, which first appeared and was detected in Wuhan last December 2019 (Danis et al., 2020; Li, Dai, Chau, \& Yip, 2021; Z. Wang, Yang, Li, Wen, \& Zhang, 2020), has had an impact on all sectors of life, such as education, economy, health, tourism, industry, transportation, and others (Pratondo \& Zaid, 2021). This clearly exacerbates socio-economic disparities around the world (Gandasari \& Dwidienawati, 2020; Susilo et al., 2020), especially in Indonesia (Gunadi Brata, Sri Astuti, Christya Rahayu, $\&$ Heron, 2021). A major unintentional event like this pandemic is further compounded by political decisions, as it still poses a social risk in society, prohibiting and limiting its consequences is clearly a social security issue (Forss, Kalimo, \& Purola, 2001). But unfortunately, according to Pecchenino \& Utendorf (1999) when analyzing the effect of social security schemes, under various and certain demographic presumptions, on economic growth as well as social welfare. they discover that in plentiful cases social security interferes with and drops economic growth and social well-being. 
For Stiglitz (2017), a country that does not provide social security for its citizens is a country with weak governance. In developed countries, such as in Europe, social security for workers, the unemployed and the elderly are very adequate. That way, if there is a crisis, both a global financial recession and a crisis due to Covid-19 as it is now, its citizens are equipped with a SafetyNet, so they have no difficulty when they have to carry out a national lockdown to save citizens. However, the Indonesian government has basically provided social security for its people, such as Social Security Administrator for Health (BPJS), the Healthy Indonesia Card, and the Smart Indonesia Card. However, BPJS in Indonesia is not handled properly and ironically, BPJS has fallen into a deficit. This then makes the solvency of Social Security has attracted wide public attention (Tsai, 2018). Whereas the effectiveness of providing national social welfare is assessed from the extent to which the state is able to provide its citizens with security, and begins to play a very important role when insecurity (health, financial, social, and others) occurs (Yur'yev, Värnik, Värnik, Sisask, \& Leppik, 2012).

Therefore, through the principles of social and economic justice, the main objectives of this article is to analyze how to grow prosperity during the recession in the moment of the COVID-19 pandemic as it is today through the strategy of providing social security to affected communities.

\section{Literature Review}

\section{The Definition and The Concept of Socio-Economic Justice}

Commitment to implementing the Global order and, preferentially, promoting socio-economic equality, begins with comprehending what human rights are, and specifically, what socio-economic rights are (Lombard \& Twikirize, 2014). Socio-economic justice is a prevalent term relating to society in most cases, human right is a term that, from the standpoint of view of society, points to certain universal standards interrelated to independence and well-being, both collective and personal rights (Lundy \& Van Wormer, 2007).

Socio-economic justice is inseparable from the concept of social and economic rights where the right of 'access' imposes a positive obligation to provide available resources to build welfare for the wider community (Lombard \& Twikirize, 2014). In terms of the "welfare triangle" consisting of the state, market, and family, it is clear that the state highly has a significant role in providing welfare guarantees to its citizens (Daigneault, 2014).

Justice is perceived by Rawls (1971) in two ways, namely equality justice in determining basic rights and obligations, and secondly justice in the form of social and economic inequalities (socioeconomic justice), especially for members of society who are the most disadvantaged (capable). This means that justice does not have to be uniform. Justice must be prioritized for the poor and disadvantaged who are deemed more in need socially for the sake of achieving equality and social welfare. This is by a study conducted by O'Brien (2011) which explored social justice. Where the results show that equality is used differently, some require equal treatment for everyone, while others focus on differential treatment to ensure equality itself. 


\section{The Definition and The Concept of Social Security}

Regarding social security, Article 1 paragraph 1 of Law Number 40 of 2004 Concerning the National Social Security System defines it as "a form of social protection to ensure that all people can fulfill their basic needs for a decent life". So that the main objective is clear "to provide guarantees for the fulfillment of basic needs for a decent life for every participant and/or member of his family" as stated in Article 3.

Ulriksen \& Plagerson (2014) argued that social security is a form of social rights. on the other hand, Stamm (2017) along with Hujo, Behrendt, \& McKinnon (2017) considered that social security is part of human rights which he calls the "Human Right to Social Security". Stamm (2017) based his opinion on the International Labor Organization in 1944 where the right to social security in an international context was first echoed. He also relies on the considerations of the Committee on Economic, Social and Cultural Rights (CESCR) which in 2007, the committee adopted the so-called General Comment No. 19 The right to social security (art. 9) contained in the general comment where in paragraph 2 it is emphasized that "The right to social security implies the right to access and maintain benefits, whether in cash or in-kind, without discrimination in order to secure protection, inter alia, from (a) lack of work-related income caused by sickness, disability, maternity, employment injury, unemployment, old age, or death of a family member; (b) unaffordable access to health care; (c) insufficient family support, particularly for children and adult dependents".

Not much different from that, In Article 82 of (Omnibus) Law no. 11 of 2020 On Job Creation which has amended Law Number 40 of 2004 concerning the National Social Security System (State Gazette of the Republic of Indonesia of 2004 Number 150, Supplement to the State Gazette of the Republic of Indonesia Number 4456) also mentions the form of social security, wherein article 18 which has been amended, it states that the type of program Social security includes health security (JK), work accident security (JKK), death security (JKM), old-age security (JHT), pension security (JP), and job loss security (JKP). and of course, all of that must be done by the state (mandatory) by the mandate of The International Covenant on Economic, Social and Cultural Rights (ICESCR) which in article 9 states that "The States Parties to the present Covenant recognize the right of everyone to social security, including social insurance". And also mandated in Article 34 paragraph (2) of the 1945 Constitution: "The state develops a social security system for all people and empowers the weak and incapable under human dignity." As well as Law Number 40 of 2004 Concerning the National Social Security System.

Therefore, social security deserves high respect because it is not only intended to provide benefits to citizens, but also to advance social and economic rights through complex social policies (Hendrianto, 2020). Battle (2021) also agrees that this is very urgent because it provides an important financial safety net for the community. especially for the people of Indonesia, where many people 
still live in poverty (Mai \& Mahadevan, 2016; Nugroho, Amir, Maududy, \& Marlina, 2021; Tohari, Parsons, \& Rammohan, 2019) and still becomes a major issue till now (Majid, Dewi, Aliasuddin, \& Kassim, 2019). And in the end, it is hoped that this social security strategy can reduce poverty (Cantillon, 2018; Couch, Reznik, Tamborini, \& Iams, 2017; Dobelstein, 2011; Meyer \& Wu, 2018) in Indonesia. because It has been known to be very effective in overcoming poverty so it is called "anti-poverty policy" (Herd, Favreault, Harrington Meyer, \& Smeeding, 2018).

\section{The Definition and The Concept of Social Welfare}

Social welfare has become a global issue and the concern of many countries and a wide spectrum of society (Dolgoff, 1999). Accroding to Barker (1987), social welfare has long been defined and conceptualized as the provision of social, economic, and health benefits for people who cannot obtain these benefits themselves. While (Mendoza-Cavazos, 2019) argued that social welfare refers to the benefits of internal and external welfare in the form of mental and physical, while sustainability refers to the balance that exists between other aspects such as economic, social, and environmental aspects of the social and economic system.

Social Welfare in Article 1 of Law No. 11 of 2009 On Social Welfare is defined as "the condition of fulfilling the material, spiritual and social needs of citizens in order to live properly and be able to develop themselves so that they can carry out their social functions". Unfortunately, on the other hand, there are many rejections and criticisms of social welfare. Many members of the public, as well as political elites, resist government actions and social welfare programs based on a political ideology rather than evidence. In their view, the social welfare programs offered and realized by the government are not effective nor competent. they also consider the program is not reliable, has costinefficient, terribly undermine self-sufficiency by encouraging dependence, and result in the collapse of economic productivity (Dolgoff, 1999).

Dolgoff (1999) further explained that social welfare program is asserted to cause a lot of disease and destruction in society. Starting from the destruction of social, moral, cultural to economic. The welfare program is also assumed by plenty of people as a negative burden for economic, social, and moral. Social Darwinism also criticizes all government social welfare (as also mentioned by Dennis, 1995 and Gordon, 2009). Where welfare programs are considered wars against poverty are disastrous because an emphasis on rights replaces a focus on needs. But if we look at it, social welfare is a very important thing for the state to ensure the life worthiness of its citizens. The welfare of the people is the main function and purpose of the establishment of the state. Therefore, creating prosperity is the mandate and responsibility of the constitution in every country (especially the welfare state) and Indonesia is no exception (Dolgoff, 1999). 
The legal basis of Law no. 11 of 2009 On Social Welfare in Indonesia are Article 18A, Article 20, Article 21, Article 23 paragraph (1), Article 27 paragraph (2), Article 28C paragraph (1), Article 28H paragraph (1), paragraph (2), and paragraph (3), and Article 34 of The 1945 Constitution. In addition to the 1945 Constitution, social welfare is also included in the view of life, the basis of the state, and the legal basis of Indonesia which is contained in the fifth precept of the 1945 Constitution of the Republic of Indonesia. Pancasila. Therefore, creating prosperity is the main mandate and responsibility of the state constitution in order to ensure that all its citizens can be protected and can satisfy their primary needs for a well-being life. However, for social welfare programs to be achieved as intended, social welfare must have a moral basis and standards of justice (Bell, 1983; Reid \& Popple, 1992).

\section{Methodology}

This study will use a lot of secondary data sources in taking data sources, so this research is research in the form of a literature review or in legal science it can also be stated as a normative legal research method (Dewata \& Achmad, 2019; Soemitro, 1983). Therefore, the approach used is also a qualitative approach and also uses a bit of a statutory approach. So that primary legal material such as legislation and secondary legal materials such as scientific books and also reputable scientific journals would be involved in this current research. The data is then gathered through a literature study through many sources available both online and offline.

\section{Result and Discussion}

\section{Building Social Welfare Through Social Security In The Middle of COVID-19 Pandemic Crisis}

Barker (1995) defined social welfare distribution as a social welfare approach that encourages and plans a model of providing social services that are in accordance with customs and culture, according to demands or regulations and available resources. And one of the ways to build social welfare based on legislation is through social security. The social security system has been constantly evolving intending to improve performance to sustain social and economic progress, however, the social security system must be expanded to promote more broadly the necessities, capabilities, and welfare of all human being as human rights (Matijascic $\&$ Mckinnon, 2014).

In accordance with Law no. 11 of 2009 which states that "social security is an institutionalized scheme to ensure that all people can fulfill their basic needs for a decent life". While in Article 84 of Law Number 11 of 2020 on Work Creation which has amended Law Number 18 of 2017 concerning the Protection of Indonesian Migrant Workers (State Gazette of the Republic of Indonesia of 2017 Number 242, Supplement to the State Gazette of the Republic of Indonesia 614) wherein article 1 paragraph 28 which has been amended it is stated that "the Guarantee Social protection is a form of social protection to ensure that all people can meet their basic needs for a decent life". And lately, social security programs have received broad support that is 
rights-based, universal, equitable, sustainable, and adequate. The social security system remains a prominent tool for sustaining economic demand, not least as a redistributive mechanism, as it is also necessary to immediately addressing inequality, relieving poverty, and reinforcing social cohesiveness within a country (McKinnon, 2019).

Therefore, during the current pandemic, the government is required to be more proactive in providing social security. A study explains that when the central government plays a proactive role by issuing several principal policies in the social security sector, it will successfully relieve the discomfort of patients infected with Covid-19 and their relatives and families from the financial burden of medication, as well as mobilize social resources entirely to restore well-being and assist the recommencement of work and production effectively (Lu, Cai, Chen, \& Liu, 2020).

Social security impacting all societies has been the focus of much debate. However, the objectives of social security policies must meet the needs of the community to reduce the impact of social change, as well as ensure the basic right of the community to survive. Social security should also promote family harmony, foster cooperation in society, and improve the quality of education. Finally, they must accumulate economic capital, and contribute to the political stability of democracy to make citizens more prosperous and have a stable and dignified life with good health (Lee \& Chang, 2006).

Social security schemes are needed to protect people from the collective risks associated with poverty, epidemics or pandemics, marginalization, crime and other risks (Forss et al., 2001). In the context of the COVID-19 crisis, social security is very significant for reducing negative risks and supporting social cohesion and human dignity. Underscores the important role of conventional social security programs to provide the necessary social protection and promote inclusive economic development (Qian, 2020). Because the main purpose of the social security program is to provide support and protection to those who are considered poor (underprivileged) or facing the threat of poverty (YU \& LI, 2021), of course, the priority in social security is to prioritize those who are less fortunate first. This is similar to John Rawls' theory of justice (1971), in which he argues that the only way society can achieve social justice is if no one cares about their position in society and special efforts are made to improve the welfare of disadvantaged groups. In other words, for society to be fair, it must be regulated in such a way that the less fortunate groups can continue to be helped (Mubyarto, 1984).

So based on the principles of socio-economic justice, in the midst of a pandemic like today, every social security must be distributed and prioritized to the underprivileged such as the poor, neglected orphans, neglected elderly people, people with physical disabilities, mental disabilities, physical and mental disabilities, former chronic disease sufferers who experience socio-economic inability problems so that their basic needs are met by Article 9 of Law no. 11 of 2009. In fact, social security is very important for future certainty in terms of income for the underprivileged people (Diamond, 2018).

And, indeed, in social welfare policy, social welfare can encourage the idea that some groups in society deserve more benefits than others (Skocpol, 1992). Because, basically, social welfare is dominated by many interest groups that are not bound symbiotically to the social structure. It is then known as "marginal groups". These marginal groups usually represent the interests of special populations who are neglected, excluded, or 
oppressed by or compared to other communities (Stoesz, 1989). This is further evidenced by the important progress that has been made in China's more effective social security system, and the creation of expanded social benefits that can reduce pressure on Chinese households to save their income as a risk management tool (Müller, 2016).

In Article 82 of (Omnibus) Law no. 11 of 2020 On Job Creation which has amended Law Number 40 of 2004 concerning the National Social Security System (State Gazette of the Republic of Indonesia of 2004 Number 150, Supplement to the State Gazette of the Republic of Indonesia Number 4456) where in article 18 which has been amended it states that the type of program Social security includes health security (JK), work accident security (JKK), death security (JKM), old-age security (JHT), pension security (JP), and job loss security (JKP). And among the six social securities, three of which are very important for the community in the midst of the current pandemic situation, namely health, death insurance, and job loss securities. And of the three social security, public health security is one of the important areas in social security. particularly during of the moment of the COVID-19 pandemic crisis.

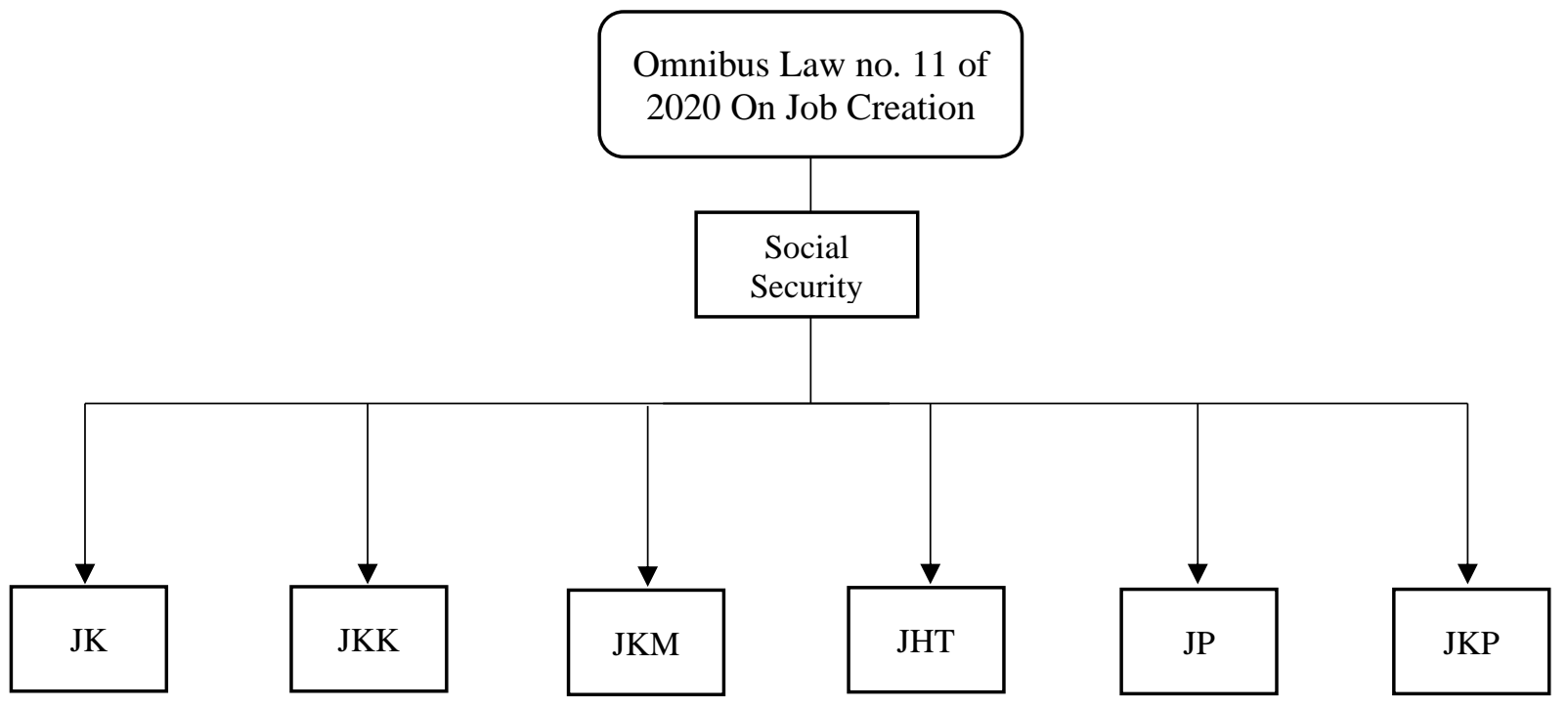

Figure 1. Six Form of Social Security

First, relating to health security, There is a saying that "When wealth is lost, nothing is lost. When health is lost, something is lost, but when a character is lost, all is lost". This COVID-19 phenomenon indicates that there is something missing (not good) that is happening in this country. Health insurance is a conceptual framework and traditional social welfare services have been dominated by the so-called 'medical model' which essentially promotes the idea that the locus of social problems stemming from physical or mental health disorders needs to be addressed (Gidron \& Monnickendam-Givon, 2017). Many countries are making great efforts to introduce or expand health coverage to ensure access to necessary services. One of them is with health insurance. Health security is a method to finance fund mobilization and risk pooling which is considered by many health policy makers to be a powerful solution for health financing. And universal coverage of health security is believed to have increased access to and utilization of health care by reducing financial barriers to providing care to those who need it most, including the poor and disadvantaged (Q. Wang, Shen, Rice, \& 
Frakes, 2018). Health security is further specifically regulated in Presidential Regulation Of The Republic Of Indonesia Number 75 Of 2019 On Amendment To Presidential Regulation Number 82 Of 2018 On Health Security.

Second, relating to work accident and death security, This combination refers to Government Regulation Of The Republic Of Indonesia Number 44 Of 2015 On Implementation Of Work Accident And Death Security Program. The regulation also defines work Accident security in Article 1 Section 1 as "a benefit in the form of cash and/or health services provided when the participant experiences a work accident or illness caused by the work environment". While in section 2 the death security (hereinafter abbreviated as JKM) is defined as "cash benefits given to heirs when the participant dies not due to work accidents". Considering that COVID19 is an occupational disease, employees are therefore very at risk and are very likely to be infected at work (Sandal \& Yildiz, 2021). Therefore, Guaranteeing workers' safety from work accidents in the workplace is a form of social security that is also very important (Song, Min, Kim, \& Min, 2019). Especially for healthcare professionals during the current COVID-19 pandemic which has claimed many victims (Ünal, 2020).

The third is old-age security, which in the midst of a pandemic is one of the social security services that experienced a fairly high spike during this COVID-19 pandemic (Indaryani, 2020). Old-age security is actually a form of giving an opportunity to someone who may have lost the ability to labor due to attaining a particular age to withdraw from work-life and enjoying life without having to work and rest (Centel, 2021). However, if referring to Government Regulation Of The Republic Of Indonesia Number 46 Of 2015 On Implementation Of The Old Age Guarantee Program where in article 1 section 1 it is stated that old-age insurance is a "cash benefit that is paid at once when the participant enters retirement age, pass away, or experience permanent total disability". Related to this, a shred of research evidence shows that about half of the elderly receive at least $50 \%$ of their family income from social security benefits, while for a quarter of the elderly social security benefits at least $90 \%$ of their family income (Dushi, Iams, \& Trenkamp, 2017). Thus, old-age security is the most important source of income for the elderly as well as a means for their welfare (Dushi et al., 2017). Therefore, through BPJS Ketenagakerjaan, every participant who has registered as a BPJS Ketenagakerjaan participant is expected to get their old age guarantee as it has also become their right. Especially in the current pandemic situation, where many studies have explained that the elderly are among the most vulnerable and most affected (Bonanad et al., 2020; Ho et al., 2020; Kang \& Jung, 2020).

Next is pension insurance, Social Security is the basis for pension insurance. Therefore, in Article 1 section 1 Government Regulation Of The Republic Of Indonesia Number 45 Of 2015 Concerning The Implementation Of The Pension Guarantee Program, it is explained that the definition of pension insurance is "social security which aims to maintain a decent standard of living for participants and/or their heirs by providing income after participants enter retirement age, permanent total disability, or death". The purpose of providing this pension guarantee is also explained in the general explanation of the regulation to provide a decent standard of living for Participants and their families who are entering Retirement Age. According to Atkins (2020), the way the pension guarantee works are by preparing most or all of the retirement income for almost half of Indonesia's workers and provide a definite basis for building supplementary wealth for the remainder. The program requires careful reform to make sure that it can keep on fulfilling this role and serve 
the needs of a changing workforce. And Social Security policy is likely to be a very useful area for implementing decisions about when to retire and when to claim benefits could have major implications for well-being during COVID-19 or even for years to come (Liebman \& Luttmer, 2015). However, the Government has also regulated the procedures for membership registration, payment, and termination of pension benefits as regulated in the Minister of Manpower Regulation Number 29 of 2015.

The last is job loss security, The Minister of State-Owned Enterprises (BUMN) revealed that as many as 3.5 million people had lost their jobs as a consequence of the Covid-19 virus pandemic. The current total unemployment in Indonesia, based on data from the Central Statistics Agency (BPS) has reached 29.12 million people (Ramalan, 2021). This is compounded by recently unemployed workers who rely on employer-based health security can not get access to sufficient health care and deal with worsening poverty due to high health care spending, encountering postponements in COVID-19 diagnosis and medication (Hoernke, 2020). In relation to this social security, the Government through Government Regulation Of The Republic Of Indonesia Number 37 Of 2021 On Implementation Of The Loss Of Job Guarantee Program has regulated the job loss guarantee. Job loss insurance itself has been defined in the regulation as "social security provided to Workers/Labourers who experience Termination of Employment in the form of cash benefits, access to job market information, and Job Training".

But unfortunately, all of this social security still represent the historical influence of the colonial era, where the focus was spotted on contribution-based social security outlines. Where only those who pay dues will get social security (Dafuleya, 2020). This of course makes other community groups (who do not participate in the social security program contributions) not have the certainty to get social security which may be needed in crises like this.

The quality of health insurance and other social security in Indonesia is also often based on premiums paid per month (in this case the same as the United States) which results in economically disadvantaged people with lower quality insurance and often lower-quality health care (Rollston \& Galea, 2020). Therefore, in the economic insight related to social security contributions (which are ultimately exacerbated by taxes) and their efficiency and effectiveness effects on social welfare, it is very important to re-identify (Goudswaard \& Caminada, 2015).

\section{Conclusion}

Social security establishes social protection to ensure that all human beings can meet their primary necessities for a well-being life. Social security is also indispensable social protection to protect the public from the collective risks associated with poverty and health risks during the moment of the Covid-19 pandemic. Therefore the state must ensure that every citizen (especially the less fortunate and unable) get social security. Based on the omnibus law on job creation law, social security has six forms including health security, work accident security, old-age security, pension security, death security, and job loss security. All these guarantees are very good and needed to make the social welfare better for Indonesian people in the moment of the COVID19 pandemic crisis. it's just that the obstacle is for those who do not pay the dues or take a part in the government's social security program. Their welfare must also be considered as mandated by the constitution 
of the 1945 Constitution. And in the principle of socio-economic justice, social security must be prioritized for the poor and disadvantaged who are felt to be more in need socially to achieve equality and social welfare.

\section{References}

Atkins, G. L. (2020). Retirement Security in a Post-Pandemic World. Public Policy \& Aging Report, 30(4), 160-165. https://doi.org/10.1093/ppar/praa027

Barker, R. L. (1987). The social work dictionary. Silver Spring: National Association of Social Workers Press.

Barker, R. L. (1995). The social work dictionary, Third Eddition. Silver Spring: National Association of Social Workers Press.

Battle, C. W. (2021). Social Security For Everyone, 2021-2022 Eddition. New York: Allworth Press.

Bell, W. (1983). Contemporary Social Welfare. New York: Macmillan.

Bonanad, C., García-Blas, S., Tarazona-Santabalbina, F., Sanchis, J., Bertomeu-González, V., Fácila, L., ... Cordero, A. (2020). The Effect of Age on Mortality in Patients With COVID-19: A Meta-Analysis With 611,583 Subjects. Journal of the American Medical Directors Association, 21, 915-918. https://doi.org/10.1016/j.jamda.2020.05.045

Cantillon, B. (2018). Social Security and Poverty Reduction in Rich Welfare States: Cracks in the Post War Policy Paradigm, Avenues for the Future. Working Papers, (1817), 1-45. Retrieved from https://ideas.repec.org/p/hdl/wpaper/1817.html

Centel, T. (2021). Old-Age Insurance. In Turkish Social Law (pp. 187-203). Springer International Publishing. https://doi.org/10.1007/978-3-030-64704-9_17

Committee on Economic, S. and C. R. UNITED NATIONS E Economic and Social Council The right to social security (art. 9). , Pub. L. No. E/C.12/GC/19 (2007). United Nation.

Couch, K. A., Reznik, G. L., Tamborini, C. R., \& Iams, H. M. (2017). The Distributional Impact of Social Security Policy Options: An Analysis of Divorced and Widowed Women. Research on Aging, 39(1), 135-165. https://doi.org/10.1177/0164027516656140

Dafuleya, G. (2020). Social and Emergency Assistance Ex-Ante and During COVID-19 in the SADC Region. The International Journal of Community and Social Development, 2(2), 251-268. https://doi.org/10.1177/2516602620936028

Daigneault, P. M. (2014). Three paradigms of social assistance. SAGE Open, 4(4). https://doi.org/10.1177/2158244014559020

Danis, K., Epaulard, O., Bénet, T., Gaymard, A., Campoy, S., Botelho-Nevers, E., ... Mounayar, A.-L. (2020). Cluster of Coronavirus Disease 2019 (COVID-19) in the French Alps, February 2020. Clinical Infectious Diseases, 71(15), 825-832. https://doi.org/10.1093/CID/CIAA424

Dennis, R. M. (1995). Social Darwinism, Scientific Racism, and the Metaphysics of Race. The Journal of Negro Education, 64(3), 243-252. https://doi.org/10.2307/2967206

Dewata, M. F. N., \& Achmad, Y. (2019). Dualisme Penelitian Hukum Normatif dan Empiris (Cetakan V) (Pustaka Pelajar, Ed.). Yogyakarta. 
Diamond, P. A. (2018). The Future Of Social Security. Economic Inquiry, 56(2), 661-681. https://doi.org/10.1111/ecin.12553

Dobelstein, A. W. (2011). Social Security: A New Paradigm for Reducing American Poverty. Poverty \& Public Policy, 3(4), 1-34. https://doi.org/10.2202/1944-2858.1218

Dolgoff, R. (1999). What does social welfare produce? International Social Work, 42(3), 295-307. https://doi.org/10.1177/002087289904200304

Dushi, I., Iams, H., \& Trenkamp, B. (2017). The Importance of Social Security Benefits to the Income of the Aged Population. Social Security Bulletin, 77(2), 1-12.

Forss, M., Kalimo, E., \& Purola, T. (2001). The Insurance Discourse and Social Security. Geneva Papers on Risk and Insurance: Issues and Practice, 26(4), 517-528. https://doi.org/10.1111/1468-0440.00137

Gandasari, D., \& Dwidienawati, D. (2020). Content Analysis of Social and Economic Issues in Indonesia During the COVID-19 Pandemic. Heliyon, 6(11). https://doi.org/10.1016/j.heliyon.2020.e05599

Gidron, B., \& Monnickendam-Givon, Y. (2017). A social welfare perspective of market-oriented social enterprises. International Journal of Social Welfare, 26(2), 127-140. https://doi.org/10.1111/ijsw.12232

Gordon, S. (2009). The Influence of Social Darwinism on Progressive Era Political Thought and Policy. The Ohio State University, Ohio.

Goudswaard, K., \& Caminada, K. (2015). Social security contributions: Economic and public finance considerations. International Social Security Review, 68(4), 25-45. https://doi.org/10.1111/issr.12086

Government Regulation Of The Republic Of Indonesia Number 37 Of 2021 On Implementation Of The Loss Of Job Guarantee Program.

Government Regulation Of The Republic Of Indonesia Number 44 Of 2015 On Implementation Of Work Accident And Death Security Program.

Government Regulation Of The Republic Of Indonesia Number 45 Of 2015 Concerning The Implementation Of The Pension Guarantee Program.

Government Regulation Of The Republic Of Indonesia Number 46 Of 2015 On Implementation Of The Old Age Guarantee Program. Republic of Indonesia.

Gunadi Brata, A., Sri Astuti, E., Christya Rahayu, H., \& Heron, H. (2021). COVID-19 and Socio-Economic Inequalities in Indonesia: A Subnational-level Analysis. ERIA Discussion Paper Series, (371), 1-32.

Hendrianto, S. (2020). Constitutionalized But Not Constitute: The Case of Right to Social Security in Indonesia. Constitutional Review, 6(2), 241-281. https://doi.org/10.31078/CONSREV623

Herd, P., Favreault, M., Harrington Meyer, M., \& Smeeding, T. (2018). A Targeted Minimum Benefit Plan: A New Proposal to Reduce Poverty Among Older Americans. Public Policy \& Aging Report, 28(suppl_1), S35-S40. https://doi.org/10.1093/PPAR/PRY022

Ho, F. K., Petermann-Rocha, F., Gray, S. R., Jani, B. D., Katikireddi, S. V., Niedzwiedz, C. L., ... Pell, J. P. (2020). Is older age associated with COVID-19 mortality in the absence of other risk factors? General population cohort study of 470,034 participants. PLOS ONE, 15(11), e0241824. https://doi.org/10.1371/JOURNAL.PONE.0241824

Hoernke, K. (2020, December 1). A socially just recovery from the COVID-19 pandemic: a call for action on 
the social determinants of urban health inequalities. Journal of the Royal Society of Medicine, Vol. 113, pp. 482-484. SAGE Publications Ltd. https://doi.org/10.1177/0141076820948817

Hujo, K., Behrendt, C., \& McKinnon, R. (2017). Introduction: Reflecting on the human right to social security. International Social Security Review, 70(4), 5-12. https://doi.org/10.1111/ISSR.12150

Indaryani, T. (2020). Klaim JHT Melonjak Imbas Pandemi, Direksi BPJAMSOSTEK Pastikan Pelayanan Tetap Prima. Retrieved June 23, 2021, from https://www.bpjsketenagakerjaan.go.id/berita/27060/KlaimJHT-Melonjak-Imbas-Pandemi,-Direksi-BPJAMSOSTEK-Pastikan-Pelayanan-Tetap-Prima

Kang, S.-J., \& Jung, S. I. (2020). Age-Related Morbidity and Mortality among Patients with COVID-19. Infection \& Chemotherapy, 52(2), 154. https://doi.org/10.3947/IC.2020.52.2.154

Law no. 11 of 2009 On Social Welfare. , (2009). Republic of Indonesia.

Law Number 11 of 2020 on Job Creation. , (2020).

Law Number 40 of 2004 concerning the National Social Security System., (2004). The Republic of Indonesia.

Lee, C. C., \& Chang, C. P. (2006). Social security expenditures and economic growth: A heterogeneous panel application. Journal of Economic Studies, 33(5), 386-404. https://doi.org/10.1108/01443580610706609

Li, W.-Y., Dai, Y., Chau, P.-H., \& Yip, P. S. F. (2021). Wuhan's experience in curbing the spread of coronavirus disease (COVID-19). International Health, 13(4), 350-357. https://doi.org/10.1093/INTHEALTH/IHAA079

Liebman, J. B., \& Luttmer, E. F. P. (2015). Would people behave differently if they better understood social security? Evidence from a field experiment. American Economic Journal: Economic Policy, 7(1), 275299. https://doi.org/10.1257/pol.20120081

Lombard, A., \& Twikirize, J. M. (2014). Promoting social and economic equality: Social workers' contribution to social justice and social development in South Africa and Uganda. International Social Work, 57(4), 313-325. https://doi.org/10.1177/0020872814525813

Lu, Q., Cai, Z., Chen, B., \& Liu, T. (2020). Social policy responses to the COVID-19 crisis in China in 2020. International Journal of Environmental Research and Public Health, 17(16), 1-14. https://doi.org/10.3390/ijerph17165896

Lundy, C., \& Van Wormer, K. (2007). Social and economic justice, human rights and peace: The challenge for social work in Canada and the USA. International Social Work, 50(6), 727-739. https://doi.org/10.1177/0020872807081899

Mai, T., \& Mahadevan, R. (2016). A research note on the poverty dynamics and cost of poverty inequality: Case study of Indonesia. Economic Analysis and Policy, 49, 100-107. https://doi.org/10.1016/J.EAP.2015.12.003

Majid, M. S. A., Dewi, S., Aliasuddin, \& Kassim, S. H. (2019). Does Financial Development Reduce Poverty? Empirical Evidence from Indonesia. Journal of the Knowledge Economy, 10(3), 1019-1036. https://doi.org/10.1007/S13132-017-0509-6

Matijascic, M., \& Mckinnon, R. (2014). Dynamic social security: A necessary condition for inclusive societies and economic development. International Social Security Review, 67(3-4), 3-15. https://doi.org/10.1111/issr.12045 
McKinnon, R. (2019). Introduction: Social security and the digital economy - Managing transformation. International Social Security Review, 72(3), 5-16. https://doi.org/10.1111/issr.12211

Mendoza-Cavazos, Y. (2019). Social Welfare and Sustainability. In Encyclopedia of Sustainability in Higher Education (pp. 1-7). Springer International Publishing. https://doi.org/10.1007/978-3-319-63951-2_3001

Meyer, B. D., \& Wu, D. (2018). The Poverty Reduction of Social Security and Means-Tested Transfers. ILR Review, 71(5), 1106-1153. https://doi.org/10.1177/0019793918790220

Minister of Manpower Regulation Number 29 of 2015 Of Procedures for Participation Registration, Payment, and Termination of Pension Guarantee Benefits.

Mubyarto, M. (1984). Social and economic justice. Bulletin of Indonesian Economic Studies, 20(3), 36-54. https://doi.org/10.1080/00074918412331334682

Müller, A. (2016). The margins and the marginalised: Social policy, labour migration, and ethnic identity in contemporary China. Journal of Current Chinese Affairs, 45(2), 3-27. https://doi.org/10.1177/186810261604500201

Nugroho, A., Amir, H., Maududy, I., \& Marlina, I. (2021). Poverty eradication programs in Indonesia: Progress, challenges and reforms. Journal of Policy Modeling. https://doi.org/10.1016/J.JPOLMOD.2021.05.002

O'Brien, M. (2011). Equality and fairness: Linking social justice and social work practice. Journal of Social Work, 11(2), 143-158. https://doi.org/10.1177/1468017310386834

Pecchenino, R. A., \& Utendorf, K. R. (1999). Social security, social welfare and the aging population. Journal of Population Economics, 12(4), 607-623. https://doi.org/10.1007/s001480050116

Pratondo, K., \& Zaid, Z. (2021). Customer Loyalty During Pandemic: Understanding Loyalty Through the Lens of Online Ride Hailing Service Quality. International Journal of Social Science and Business, 5(1), 69-75. https://doi.org/10.23887/IJSSB.V5I1.30933

Presidential Regulation Of The Republic Of Indonesia Number 75 Of 2019 On Amendment To Presidential Regulation Number 82 of 2018 On Health Security. Republic Of Indonesia.

Qian, X. (2020). China's social security response to COVID-19: Wider lessons learnt for social security's contribution to social cohesion and inclusive economic development. International Social Security Review, 73(3), 81-100. https://doi.org/10.1111/issr.12246

Ramalan, S. (2021, January 22). 3,5 Juta Orang Kehilangan Pekerjaan Akibat Pandemi Covid-19. Retrieved June 23, 2021, from https://www.idxchannel.com/market-news/35-juta-orang-kehilangan-pekerjaanakibat-pandemi-covid-19

Rawls, J. (1971). A Theory of Justice. Oxford: Oxford University Press.

Reid, P. N., \& Popple, P. R. (1992). The Moral Purposes of Social Work. Chicago: Nelson-Hall.

Rollston, R., \& Galea, S. (2020, July 1). COVID-19 and the Social Determinants of Health. American Journal of Health Promotion, Vol. 34, pp. 687-689. SAGE Publications Inc. https://doi.org/10.1177/0890117120930536b

Sandal, A., \& Yildiz, A. N. (2021). COVID-19 as a Recognized Work-Related Disease: The Current Situation 
Worldwide. Safety and Health at Work, 12(1), 136-138. https://doi.org/10.1016/J.SHAW.2021.01.001 Skocpol, T. (1992). Protecting Soldiers and Mothers: The Political Origins of Social Policy in the United States. Cambridge, Massachusetts: Belknap Press.

Soemitro, R. H. (1983). Metodologi Penelitian Hukum. jakarta: Ghalia Indonesia.

Song, S. H., Min, J. Y., Kim, H. J., \& Min, K. B. (2019). Topic modeling to mind illegal compensation for occupational injuries. European Journal of Public Health, 29(Supplement_4). https://doi.org/10.1093/eurpub/ckz186.317

Stamm, I. (2017). The Human Right to Social Security and Its Impact on Socio-Political Action in Germany and Finland. Journal of Human Rights and Social Work, 2(1-2), 25-33. https://doi.org/10.1007/S41134017-0030-7

Stiglitz, J. E. (2017). Globalization and Its Discontents Revisited: Anti-Globalization in the Era of Trump. United Kingdom: W. W. Norton \& Company.

Stoesz, D. (1989). A theory of social welfare. Social Work (United States), 34(2), 101-107. https://doi.org/10.1093/sw/34.2.101

Susilo, A., Rumende, C. M., Pitoyo, C. W., Santoso, W. D., Yulianti, M., Herikurniawan, H., .. Yunihastuti, E. (2020). Coronavirus Disease 2019: Tinjauan Literatur Terkini. Jurnal Penyakit Dalam Indonesia, 7(1), 45. https://doi.org/10.7454/JPDI.V7I1.415

The 1945 Constitution. , (1945). The Republic of Indonesia.

The International Covenant on Economic, Social and Cultural Rights. United Nations.

Tohari, A., Parsons, C., \& Rammohan, A. (2019). Targeting poverty under complementarities: Evidence from Indonesia's unified targeting system. Journal of Development Economics, 140, 127-144. https://doi.org/10.1016/J.JDEVECO.2019.06.002

Tsai, Y. (2018). Social Security Income and Health Care Spending: Evidence from the Social Security Notch. Scandinavian Journal of Economics, 120(2), 440-464. https://doi.org/10.1111/sjoe.12218

Ulriksen, M. S., \& Plagerson, S. (2014). Social Protection: Rethinking Rights and Duties. World Development, 64, 755-765. https://doi.org/10.1016/J.WORLDDEV.2014.07.009

Ünal, Ö. (2020). During COVID-19, which is more effective in work accident prevention behavior of healthcare professionals: Safety awareness or fatalism perception? Work, 67(4), 783-790. https://doi.org/10.3233/WOR-203327

Wang, Q., Shen, J., Rice, J., \& Frakes, K. (2018). Social Health Insurance Difference in Inpatient Expenditure and Service Category in China. Asia-Pacific Journal of Public Health, 30(1), 56-66. https://doi.org/10.1177/1010539517751745

Wang, Z., Yang, B., Li, Q., Wen, L., \& Zhang, R. (2020). Clinical features of 69 cases with coronavirus disease 2019 in Wuhan, China. Clinical Infectious Diseases, 71(15), 769-777. https://doi.org/10.1093/CID/CIAA272

YU, L. rong, \& LI, X. yun. (2021). The effects of social security expenditure on reducing income inequality and rural poverty in China. Journal of Integrative Agriculture, 20(4), 1060-1067. https://doi.org/10.1016/S2095-3119(20)63404-9 
Yur’yev, A., Värnik, A., Värnik, P., Sisask, M., \& Leppik, L. (2012). Role of social welfare in European suicide prevention. International Journal of Social Welfare, 21(1), 26-33. https://doi.org/10.1111/j.14682397.2010.00777.x 